Plant Tissue Cult. \& Biotech. 29(1): 63-72, 2019 (June) $\overline{\text { PTC\&B }}$

\title{
In vitro Microtuber Induction and Regeneration of Plantlets from Microtuber Discs of Cultivated Potato (Solanum tuberosum L.)
}

\author{
Rita Sarah Borna*, M. I. Hoque and R. H. Sarker \\ Plant Breeding and Biotechnology Laboratory, Department of Botany, University of Dhaka, \\ Dhaka 1000, Bangladesh
}

Key words: Potato, In vitro regeneration, Microtuber, Microtuber disc, Periderm

\begin{abstract}
In vitro microtuber induction potential of a popular potato (Solanum tuberosum L.) variety Diamant was examined using different supplements of growth regulators. Results showed that MS supplemented with $4.0 \mathrm{mg} / \mathrm{BAP}, 1.0 \mathrm{mg} / \mathrm{IAA}$ and $1.0 \mathrm{mg} / \mathrm{GA} 3$ produced the best response towards microtuber induction from in vitro raised stem cuttings. Further, these in vitro raised microtubers were used to establish a highly efficient shoot regeneration system. Highest number of regenerated shoots were obtained from the peripheral region of microtuber disc explant on the MS containing $4.0 \mathrm{mg} / \mathrm{BAP}$ and $2.0 \mathrm{mg} / \mathrm{IAA}$. Histological analysis revealed that microtuber periderm was composed of a several layers of uniform meristematic phellogen cells which were responded to growth hormones in the above mentioned medium producing healthy multiple shoots. Effective roots developed from these in vitro raised shoots on half strength of MS with $0.2 \mathrm{mg} / \mathrm{IBA}$. The plantlets were eventually acclimatized in pots containing soil for their establishment.
\end{abstract}

\section{Introduction}

Potato (Solanum tuberosum L.) belongs to Solanaceae is the main non-cereal crop for the world population. Potato is a global crop, and in Bangladesh potato is the second largest crop (by weight) after rice. In the year 2017, approximately 10216 MT potato produced in Bangladesh and currently 4,71,013 ha lands are used for potato cultivation (BBS 2017). In Bangladesh, the conventional method of potato propagation is by seed tubers which are most of the time contaminated with pathogens. To get disease free plants particularly virus free planting materials, farmers can use in vitro grown microtubers and plantlets obtained through meristem culture. Because of smaller size and less weight, microtubers

*Author for correspondence: \borna_rs@du.ac.bd>. 
are easier to handle, transport and store than plantlets or conventional seed tuber potatoes. Additionally, it has been reported that microtuber derived plants have higher yield compared to seed tuber derived plants (Hossain et al. 2017). Microtubers are small tubers, produced in the place of axillary buds of in vitro growing shoots on high sucrose medium (Jones 1994). In vitro microtuberization was first reported by Baker in 1953. The effect of plant growth hormones and nutrients on microtuberization of different potato varieties has been reported by several authors. It was reported that BAP can enhance microtuber induction and modify dormancy duration, but higher concentration of BAP can increase days to tuberization (Wang and $\mathrm{Hu} 1982$ and 1985). BAP with CCC (chlorocholine chloride) can also induce in vitro microtuberization (Tover et al. 1985). It was also reported that MS with BAP, coumarin and coconut water can also induce microtuber formation (Prematilake and Mendis 1998). On the other hand, it has been reported by several authors that $\mathrm{GA}_{3}$ can enhance stolon formation but inhibit microtuber induction (Garcia-Torres and Gomez-Campo 1973, Stallknecht and Farnsworth 1982 and $\mathrm{Xu}$ et al. 1998). But medium with $\mathrm{Kn}$ and $\mathrm{GA}_{3}$ can induce microtuberization (Kumar et al. 1995). The effect of auxins on microtuber induction is not well studied yet. In a preliminary investigation, it was found that spontaneous microtuberization can be induced in six to seven weeks old culture of shoots in medium containing BAP and IAA (Borna et al. 2010).

For in vitro micropropagation of potato, node and internode segments of stem usually used as explants (Hussey and Stacey 1981, Bajaj 1981, Miller et al. 1985 and Hossain 1994). Because of high shoot regeneration efficiency, node and internodes are also used as explant for infection during Agrobacterium-mediated genetic transformation (Sarker and Mustafa 2002, Sultana 2005 and Borna et al. 2010).

As microtubers are modified stem, regeneration efficiency of microtuber discs were also studied in the present set of experiments. Shoot regeneration from the eye tissue of microtuber has been reported earlier (Snyder and Belknap 1993). It was also reported that isolated pith or core tissue of microtuber can produce shoots in MS with Zn and IAA (Prematilake and Mendis 1998). In that case callus was derived from pith tissue first and then shoots regenerated from callus. Whole microtuber discs were also used for regeneration in medium containing Zn and IAA (Kumar et al. 1995). However, to date no single method has been developed to get large number of shoots from microtuber explants. Therefore, present authors developed an efficient regeneration protocol for shoot propagation from microtuber discs. The developed protocol can be used in other in vitro techniques like plant genetic transformation.

The immature potato tuber priderm is made up of three layers, i.e., phellem, phellogen and phelloderm cells. Meristematic phellogen is the cork cambium, that gives rise to neighbouring phellem and phelloderm cells during development (Lulai and Freeman 2001, Sabba and Lulai 2002). The histological analysis of microtuber showed 
that the microtuber periderm is made up of multiple layer of meristematic phellogen cells which basically give rise to large number of multiple shoots in the regeneration medium.

\section{Materials and Methods}

Potato (Solanum tuberosum var. Diamant) tubers were collected from Bangladesh Agricultural Research Institute (BARI), Joydevpur, Gazipur.

Tubers were kept in the $4^{\circ} \mathrm{C}$ refrigerator for 7 days to break the dormancy and induction of sprouts. After 7 days cold treatment, tubers were kept in the dark chamber for two weeks at $25 \pm 2{ }^{\circ} \mathrm{C}$ for the development of sprouts. Long sprouts $(2.0 \mathrm{~cm})$ were then used as primary explants for the establishment of in vitro cultures (Fig. 1A). For in vitro culture, sprouts were first rinsed three times with sterile water and then surface sterilized with $0.1 \% \mathrm{HgCl}_{2}$. The surface sterilized sprouts were then cultured on MS supplemented with $4.0 \mathrm{mg} / \mathrm{BAP}$ and $1.0 \mathrm{mg} / \mathrm{IAA}$ (Borna et al. 2010). The medium was solidified with $0.8 \%$ agar and $\mathrm{pH}$ was adjusted to 5.8 before autoclaving. In vitro cultures were maintained in a growth room at a temperature of $25 \pm 2{ }^{\circ} \mathrm{C}$, and a photoperiod of $16 / 8 \mathrm{hrs}$ light/darkness supplemented with fluorescent lights. For microtuber induction, stem cuttings from in vitro grown shoots were cultured on MS supplimentd with various concentrations and combinations of growth regulators like BAP, IAA, GA 3 and 9\% sucrose. Cultures were kept at $25 \pm 2{ }^{\circ} \mathrm{C}$ and $24 \mathrm{hrs}$ darkness. In vitro grown microtubers were sliced to thin disc by hand section with sterile blade. The thickness of tuber discs was about $0.5 \mathrm{~cm}$. Tuber discs were then placed on MS supplimented with various concentrations and combinations of BAP and IAA. Culture flasks were maintained in $25 \pm 2{ }^{\circ} \mathrm{C}$ and a photoperiod of 16/8 hrs light/darkness. For induction of roots, $3-4 \mathrm{~cm}$ long shoots were placed on MS (half strength) with $0.2 \mathrm{mg} /$ IBA (Borna et al. 2010). Plantlets with proliferated roots were placed to autoclaved pot soil and hardened at growth room to acclimatize with environment. For acclimatization, plantlets with pots were covered with porous plastic bags and gradually leave the bag open for longer periods.

For histological analysis, $1 \mathrm{~cm}$ long In vitro microtubers were hand sectioned by blade. Sections were mounted in $0.1 \%$ aneline blue and observed under fluorescent microscope (Nikon ECLIPSE 50i). Photographs were taken using a camara (Nikon DIGITAL SIGHT DS-Fi2) attached to microscope.

ANOVA and Tukey HSD were performed for statistical analysis by using Microsoft excel 2016 and $\mathrm{R}$ based tools.

\section{Results and Discussion}

In vitro shoot cultures of potato var. Diamant was developed from ex vitro grown potato tuber sprouts. Ms supplemented with $4.0 \mathrm{mg} / \mathrm{BAP}$ and $1.0 \mathrm{mg} / \mathrm{IAA}$ (Borna et al. 2010) 
was used to initiate and maintain in vitro shoot cultures. Further, microtubers were induced from in vitro grown shoots by using stem cuttings on MS supplemented with various combinations of BAP, IAA and GA3 under continuous dark condition. It was found that concentration of growth regulators can influence the days to microtuberization. In the medium containing only $4.0 \mathrm{mg} / \mathrm{BAP}$ can induce tuber approximately 44 days. On the other hand, MS supplemented with $4.0 \mathrm{mg} / \mathrm{BAP}, 1.0$ $\mathrm{mg} / \mathrm{IAA}$ and $1.0 \mathrm{mg} / \mathrm{GA}_{3}$ can reduce the days to 41 . These values were statistically significant following ANOVA analysis. In case of average number of microtuber/plant, 1.1 to 1.4 tubers observed and there were no statistically significant differences found between different growth regulator combinations (Table 1, Fig. 1). Previously it has been reported that microtubers can spontaneously form from six to seven weeks old shoots in MS with $4.0 \mathrm{mg} / \mathrm{BAP}$ and $1.0 \mathrm{mg} / \mathrm{IAA}$ (Borna et al. 2010). Therefore, in this set of experiments growth regulator treatments started from $4.0 \mathrm{mg} / \mathrm{BAP}$ and gradually different concentrations of IAA and GA3 was added with BAP to see the response towards microtuberization. In previous study, it has been showed that cytokinins can enhance microtuberization (Wang and $\mathrm{Hu}$ 1985), but higher concentration of BAP (10 $\mathrm{mg}$ A) can increase days (16 weeks) to microtuberization (Wang and $\mathrm{Hu}$ 1982). It was also reported that MS with BAP (5.0 $\mathrm{mg} \Lambda)$, CCC (500 $\mathrm{mg} /$ ) with $8 \%$ sucrose can induce microtuberization (Tover et al. 1985). Prematilake and Mendis (1998) reported that MS with BAP $(1.0 \mathrm{mg} /)$, coumarin $(50.0 \mathrm{mg} /)$, coconut water $(10 \% \mathrm{v} / \mathrm{N})$ and sucrose $(8 \%) \mathrm{can}$ induce microtubers. Fufa and Diro 2014, reported the effect of different concentrations of sucrose on microtuber production. Hossain et al. 2017 used $10.0 \mathrm{mg} / \mathrm{BA}$ for microtuber induction. Present study indicated that along with BAP, IAA and GA3 can induce microtuberization and reduce the days to tuberization.

The efficacy of in vitro grown microtuber as an explant for multiple shoot regeneration has been experimented. Microtubers were sectioned into thin discs and cultured on MS with growth regulators. Pale green calli were found to develop from all over the outer circle of tuber disc after two weeks of initial culture. After four to five weeks of initial culture, shoot initiation started from green callus. About $83 \%$ discs responded towards callus formation and approximately 6.69 shoots/tuber disc were obtained in the MS with $4.0 \mathrm{mg} / \mathrm{BAP}$ and $0.5 \mathrm{mg} /$ IAA. In the medium with $4.0 \mathrm{mg} / \mathrm{BAP}$ and $1.0 \mathrm{mg} / \mathrm{IAA}, 80 \%$ discs responded to callus formation and approximately 8.48 shoots/tuber disc were obtained. Remarkabelly, in the MS with $4.0 \mathrm{mg} / \mathrm{BAP}$ and $1.5 \mathrm{mg} / \mathrm{IAA}, 4.0 \mathrm{mg} / \mathrm{BAP}$ and $2.0 \mathrm{mg} / \mathrm{IAA}$, and $4.0 \mathrm{mg} / \mathrm{BAP}$ and 2.5 mg 1 IAA showed approximately 82,88 and $86 \%$ responses regarding callus formation and about 23.39, 23.51 and 23.54 shoots/tuber disc were obtained, respectively. All these results were statistically significant. These results indicated that the growth regulators combination $4.0 \mathrm{mg} / \mathrm{BAP}$ and $1.5 \mathrm{mg} / \mathrm{IAA}$ is the threshold point for sudden increase of shoots/tuber disc and after that, additional amount of IAA did not contribute to increase shoot number/disc (Fig. 2C, Table. 2). After shoot formation, half strength MS with $0.2 \mathrm{mg} / \mathrm{IBA}$ 
was used for root induction and proliferation (Borna et al. 2010). In vitro grown plantlets were acclimatized to pot soil (Fig. 3).
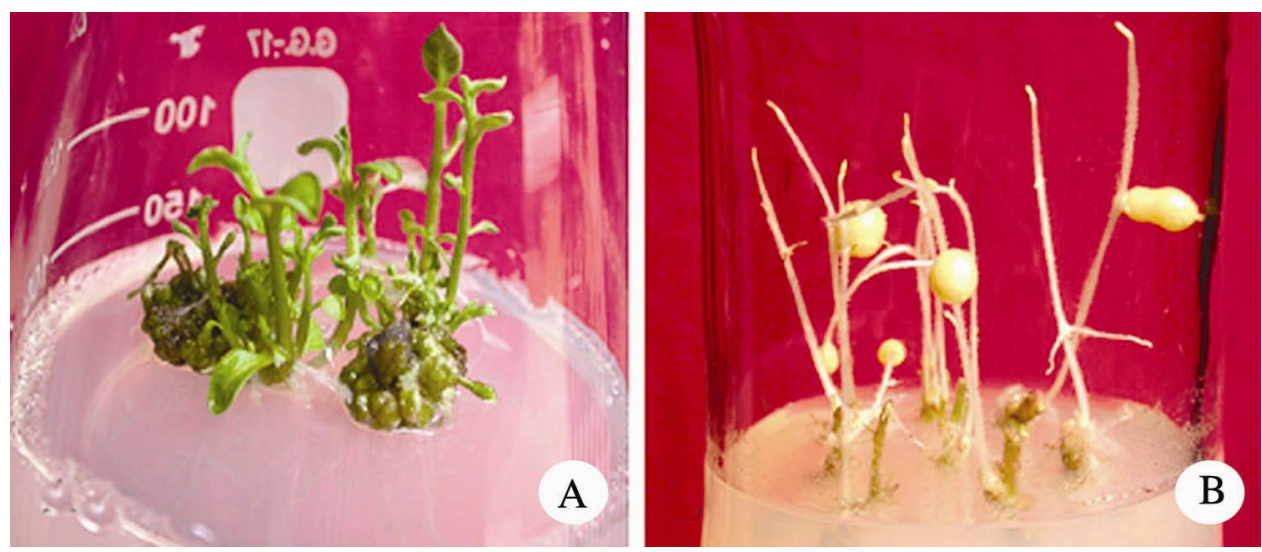

Fig. 1. In vitro microtuber induction. A. Regenerated shoot in primary culture containing MS supplimented with $4.0 \mathrm{mg} / \mathrm{BAP}$ and $1.0 \mathrm{mg} / \mathrm{IAA}$. B. Microtubers formed from stem cuttings of primary culture in tuber induction medium (MS supplemented with $4.0 \mathrm{mg} /$ ).

Table.1. Effects of BAP, IAA and $\mathrm{GA}_{3}$ on microtuberization from regenerated shoots of potato.

\begin{tabular}{lcc}
\hline $\begin{array}{l}\mathrm{BAP}+\mathrm{IAA}+\mathrm{GA}_{3} \\
(\mathrm{mg} /)\end{array}$ & $\begin{array}{c}\text { Av. days to } \\
\text { microtuberization }\end{array}$ & $\begin{array}{c}\text { Av. microtuber no./plant } \\
\text { (8 weeks of culture) }\end{array}$ \\
\hline a. $4.0+0+0$ & $44.3 \pm 1.49$ & $1.2 \pm 0.42$ \\
b. $4.0+0.5+0$ & $44.6 \pm 1.67$ & $1.4 \pm 0.69$ \\
c. $4.0+1.0+0.0$ & $44.4 \pm 1.08$ & $1.2 \pm 0.42$ \\
d. $4.0+0.5+0.5$ & $43.0 \pm 1.76$ & $1.2 \pm 0.42$ \\
e. $4.0+1.0+0.5$ & $42.7 \pm 1.33$ & $1.1 \pm 0.32$ \\
f. $4.0+1.0+1.0$ & $41.6 \pm 0.96^{* *}$ & $1.2 \pm 0.42$ \\
\hline
\end{tabular}

Values are mean $\pm \mathrm{Sd}$; Statistical analysis was done using the Tukey HSD test. ${ }^{* *}=\mathrm{p}<0.01$ where $\mathrm{f}$ was compared with a.

Esna-Ashari and Villiers 1998, reported plant regeneration from tuber disc by using BAP and showed the anatomical features associated with plant regeneration. They found that at first meristematic nodules produced from the tuber discs and then shoots were regenerated from meristematic region. Previously, microtuber core tissues were used for plantlet production (Prematilake and Mendis 1999). Okazawa et al. 1967 and Lam S-L 1975 reported shoot regeneration from the ex vitro grown tuber pith tissue. Shoot regeneration from leaf and node explants of in vitro grown shoots has already been reported in several studies (Hussey and Stacey 1981, Miller et al. 1985, Islam 1990, Mila 
1991, Hossain 1994, Bajaj 1981, Khan and Rabbani 1999, Sarker and Mustafa 2002, Sultana 2005 and Borna et al. 2010).
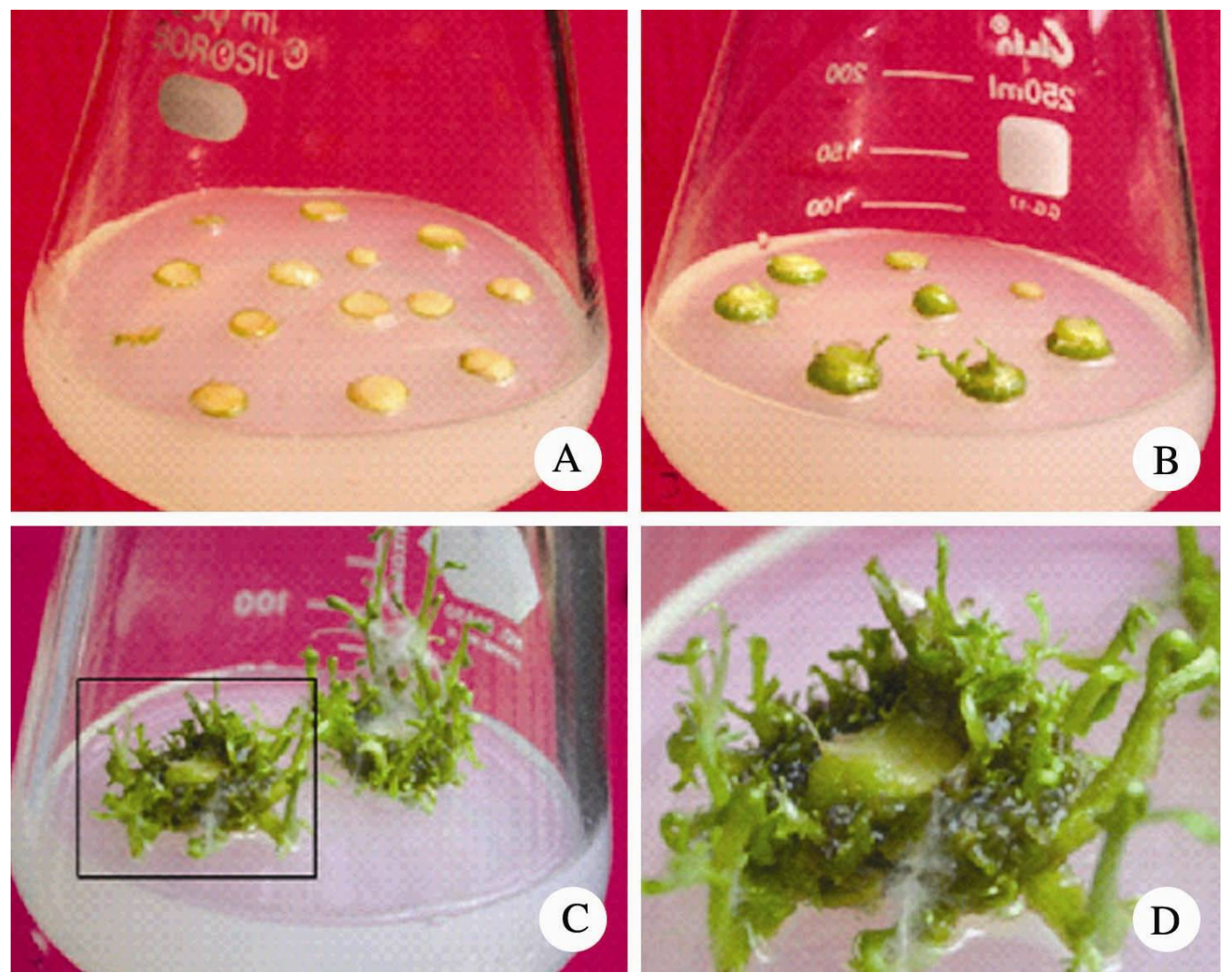

Fig. 2. Shoot regeneration from microtuber. A. Microtuber disc cultured on regeneration medium containing MS with $4.0 \mathrm{mg} / \mathrm{BAP}$ and $2.0 \mathrm{mg} / \mathrm{IAA}$. B. Same as A but green calli induced from tuber disc surface. $C$. Regenerated shoots from the tuber disc along the periphery. D. Same as $\mathrm{C}$ but showing a magnified view.

This study showed that like other explants, microtuber disc could be a potential explant for shoot regeneration and can be used for Agrobacterium-mediated plant genetic transformation since the entire surface of the microtuber disc creates a wide area as well as cut surface required for Agbrobacterial infection during transformation.

From shoot regeneration study it was found that all the shoots are initiated from the outer surface of the tuber disc. Therefore, histological analysis of microtuber was done to identify the nature of the cells of microtuber periderm which responded to shoot initiation. From fluorescent microscopic observation, it was found that the periderm of microtuber is composed of uniform parenchymatous cells which are supposed to be phellogen (cork cambium) cells (Fig. 4). Previously histological study of ex vitro grown 

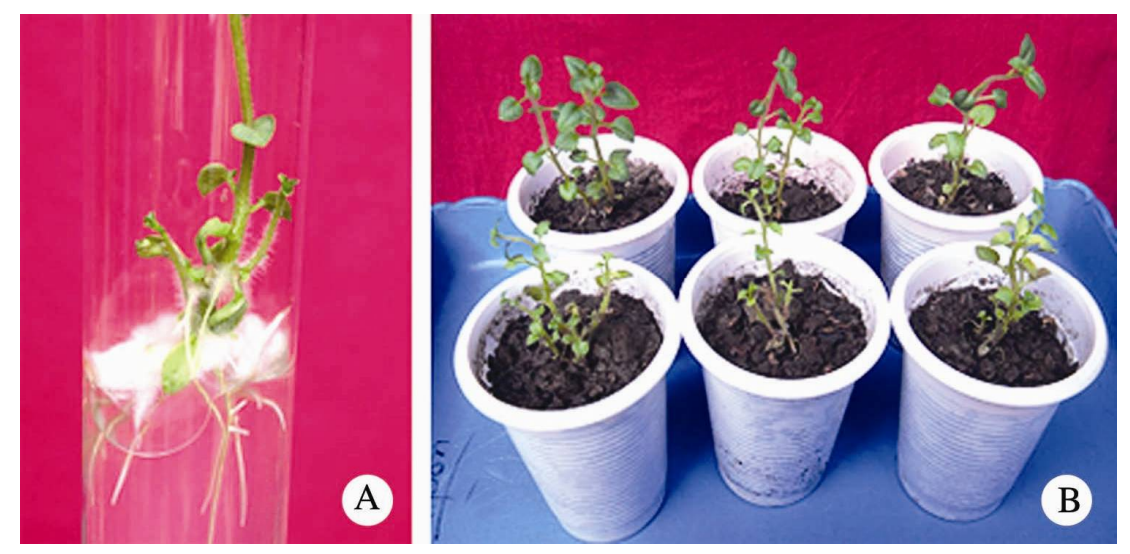

Fig. 3. A. Rooting of shoots and B. plantlets in pot soil.

Table 2. Effects of BAP and IAA on callus formation and shoot regeneration from microtuber disc.

\begin{tabular}{lcc}
\hline $\begin{array}{l}\text { BAP + IAA } \\
(\mathrm{mg} A)\end{array}$ & $\begin{array}{c}\text { \% of responsive tuber disc } \\
\text { (in two weeks of culture) }\end{array}$ & $\begin{array}{c}\text { Average number of shoot/tuber } \\
\text { disc (in ten weeks of culture) }\end{array}$ \\
\hline $4.0+0.5$ & 83.33 & $6.69 \pm 1.76^{\mathrm{a}}$ \\
$4.0+1.0$ & 80.00 & $8.48 \pm 1.82^{\mathrm{b}}$ \\
$4.0+1.5$ & 82.50 & $23.39 \pm 2.38^{\mathrm{c}}$ \\
$4.0+2.0$ & 88.57 & $23.51 \pm 2.60^{\mathrm{c}}$ \\
$4.0+2.5$ & 86.00 & $23.54 \pm 1.65^{\mathrm{c}}$ \\
\hline
\end{tabular}

Means with the same letters in a column are not significantly different from each other using the Tukey HSD test at $\mathrm{p}<0.05$. Values are mean $\pm \mathrm{Sd}$.

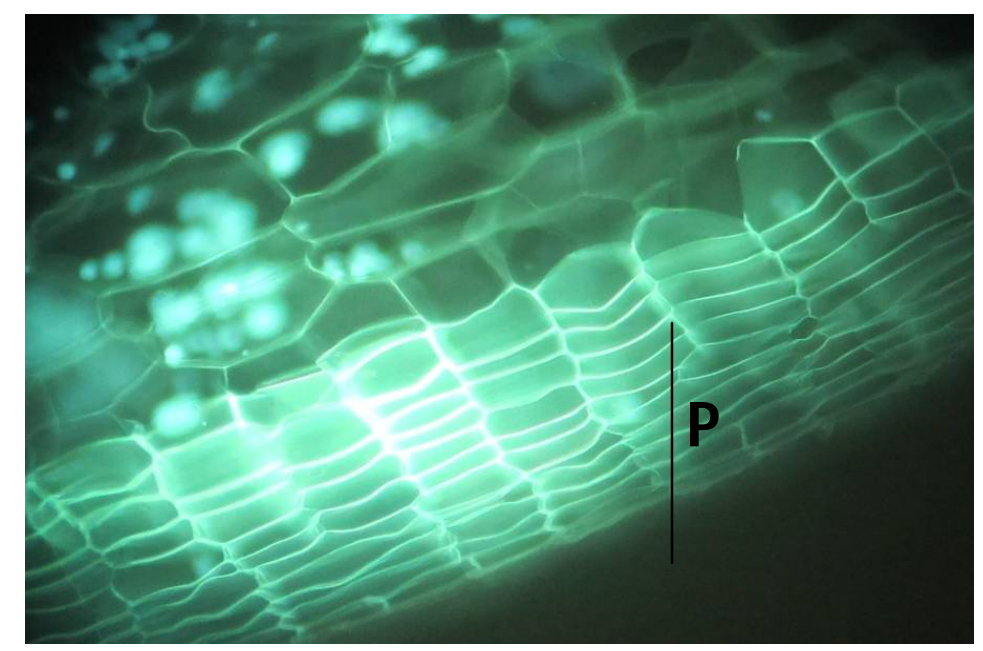

Fig. 4. The transverse section of microtuber under fluorescence microscope showing a large number of uniform parenchymatous cells (P). Regeneration of shoots occurred from this layer of cells. 
immature tuber showed that the periderm is made up of phellem, phellogen and phelloderm, where phellogen is the meristematic cambium which gradually gives rise to neighbouring phellem and phelloderm cells during development (Lulai and Freeman 2001, Sabba and Lulai 2002). In this study, in presence of growth regulators, these phellogen cambial tissues responded to callus formation and subsequent regeneration of shoots. Therefore, the entire outer surface of microtuber disc was found to develop shoots and the internal tissues of the microtuber disc did not respond to regeneration under in vitro condition.

In vitro microtuberization and a highly efficient shoot regeneration system from microtuber has been established for potato variety Diamant. Further histological study of microtuber revealed that microtuber periderm is made up of multiple layers of meristematic phellogen cells which confer microtuber disc as a potential explants for multiple shoot regeneration.

\section{Acknowledgements}

Authors are grateful to Professor M.M. Haque and Professor Nurul Islam for their suggestions during the preparation of this manuscript and critically going through it. The authors are also thankful to BARI authorities for providing the potato tubers for this investigation.

\section{References}

Bajaj YPS (1981) Regeneration of plants from potato meristems freeze preserved for 24 months. Euphytica 30(1): 141-145.

Barker WG (1953) A method for the in vitro culturing of potato tubers. Science 118: 384-385.

BBS (2017) Bangladesh Bureau of Statistics, Agriculture Wing. Ministry of Planning, People's Republic of Bangladesh.

Borna RS, Hoque MI and Sarker RH (2010) Agrobacterium mediated genetic transformation for local cultivars of potato (Solanum tuberosum L.) using marker genes. Plant Tissue Cult. 20(2): 145-155.

Esna-Ashari M and Villiers TA (1998) Plant regeneration from tuber discs of potato (Solanum tuberosum L.) using 6-benzylaminopurine (BAP). Potato Res. 41: 371. doi:10.1007/ BF02358969

Fufa M and Diro M (2014) Microtuber induction of two potato (Solanum tuberosum L.) varieties. Adv. Crop Sci. Tech. 2:122. doi:10.4172/2329-8863.1000122

Garcia-Torres L and Gomez-Campo C (1973) In vitro tuberization of potato sprouts as affected by ethrel and gibberellic acid. Potato Res. 16: 73-79.

Hossain MJ (1994) In vitro propagation of potato (Solanum tuberosum L.). Plant Tissue Cult. 4(1): 33-37. 
Hossain MS, Hossain MM, Haque MM, Haque MM and SarkarMD (2017) Varietal evaluation of potato microtuber and plantlet in seed tuber production. International Journal of Agronomy. Article ID 7520297 doi: 10.1155/2017/7520297

Hussey G and Stacey NJ (1981). In vitro propagation of potato (Solanum tuberosum L.) Ann. Bot. 48: 787-796.

Islam A (1990) Studies of in vitro microtuber formation in potato (Solanum tuberosum L.). M. Sc. thesis, Plant Breeding and Tissue Culture Lab., Department of Botany, University of Dhaka.

Jones MGK (1994) In vitro culture of potato. Plant cell and tissue culture. (Ed. I. K. Vasil and T. A. Thorpe) pp. 363-378, Kluwer Academic Publishers, Netherlands.

Khan SAKU and Rabbani MG (1999). Effect of preincubation of tubers on in vitro culture of three potato varieties. Plant Tissue Cult. 9(1): 1-9.

Kumar A, Miller M, Whitty 1, Lyon J and Davie P (1995) Agrobacterium-mediated transformation of five wild Solanum species using in vitro microtubers. Plant Cell Reports 14: 324-328

Lam S-L (1975) Shoot formation in potato tuber discs in tissue culture. American Potato Journal 52: 103-106.

Lulai EC and Freeman TP (2001) The importance of phellogen cells and their structural characteristics in susceptibility and resistance to excoriation in immature and mature potato tuber (Solanum tuberosum L.) Periderm. Ann. Bot. 88(4.1): 555-561. doi:10.1006/anbo.2001.1497.

Mila NB (1991) Optimization of in vitro microtuber formation in potato (Solanum tuberosum L.). M. Sc. thesis, Plant Breeding and Tissue Culture Lab., Department of Botany, University of Dhaka.

Miller PR, Amirouche L, Stuchbury T and Mathews S (1985) The use of plant growth regulators in micropropagation of slow-growing potato cultivars. Potato Research 28: 479-486.

Okazawa Y, Katsura N, Tagawa T (1967) Effects of auxin and kinetin on the development and differentiation of potato tissue cultured in vitro. Physiologia Plantarum 20: 862-869.

Prematilake DP and Mendis MH (1998) Microtuber of potato (Solanum tuberosum L.): In vitro conservation and tissue culture. J. Natn. Aci. Foundation Sri Lanka 1999 27(1): 17-28.

Sabba RP, Lulai EC (2002) Histological analysis of the maturation of native and wound periderm in potato (Solanum tuberosum L.) Tuber. Ann Bot. 90(1): 1-10. doi:10.1093/aob/mcf147

Sarker RH and Mustafa BM (2002) Regeneration and Agrobacterium-mediaied genetic transformation of two indigenous potato varieties of Bangladesh. Plant Tissue Cult. 12(1): 69-77.

Stallknecht GF and Farnsworth S (1982) General characteristics of coumarin-induced tuberization of axillary shoots of Solanum tuberosum L. cultured in vitro. Amer. Potato J. 59: 17-32.

Sultana P (2005) In vitro regeneration and Agrobacterium-mediate genetic transformation of potato (Solanum tuberosum L.), M. S. thesis, Plant Breeding and Biotechnology lab., Department of Botany, University of Dhaka.

Snyder GW and Belknap WR (1993) A modified method for routine Agrobacterium-mediated transformation of in vitro grown potato microtubers. Plant Cell Rep. Apr. 12(6): 324-7. doi:10.1007/BF00237428.

Tover P, Estrada R, Schilde-Rentschler L and Dodds JH (1985) Induction and use of in vitro potato tubers. CIP Circular 13(4): 1-5 
Wang P and Hu C (1982) In vitro mass tuberization and virus free seed potato production in Taiwan. Amsterdam Potato Journal 59: 33-37.

Wang P and Hu C (1985) Potato tissue culture and it's applications in agriculture. pp. 503-577. In:: P. H. Li, ed. Potato physiology. New York: Academic press.

Xu X, Lammeren AAMV, Vermeer E and Vreugdenhil D (1998) The role of gibberellin, abscisic acid, and sucrose in the regulation of potato tuber formation in vitro. Plant Physiol. 117: 575-584.

(Manuscript received on 10 March, 2019; revised on 16 May, 2019) 